\title{
Data report: porosity and pore size characteristics of sediments from Site C0002 of the Nankai Trough determined by mercury injection ${ }^{1}$
}

\author{
Brandon Dugan²
}

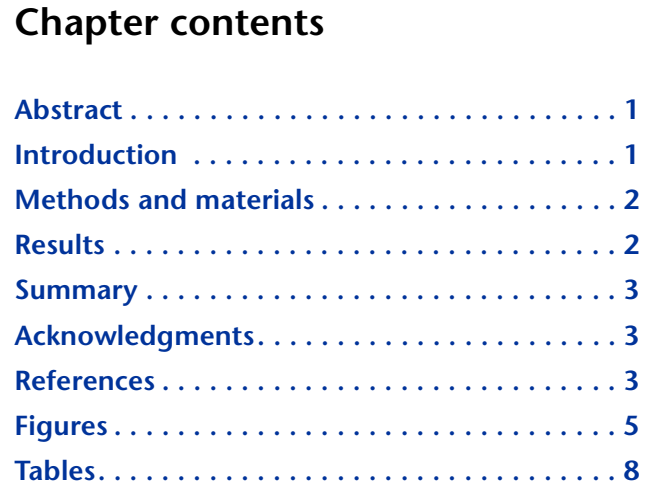

${ }^{1}$ Dugan, B., 2015. Data report: porosity and pore size characteristics of sediments from Site C0002 of the Nankai Trough determined by mercury injection. In Strasser, M., Dugan, B., Kanagawa, K., Moore, G.F., Toczko, S., Maeda, L., and the Expedition 338 Scientists, Proc. IODP, 338: Yokohama (Integrated Ocean Drilling Program).

doi:10.2204/iodp.proc.338.202.2015

${ }^{2}$ Department of Earth Science, Rice University, Houston TX 77005, USA

dugan@rice.edu

\begin{abstract}
Mercury injection capillary pressure (MICP) measurements constrain pore-scale physical properties of mud(stone) bulk cuttings ( $>4 \mathrm{~mm}$ fraction) and core samples from Integrated Ocean Drilling Program Site C0002. Core samples from 221-464 meters below seafloor (mbsf) in the Kumano forearc basin have porosities of $0.40-0.56$, median pore throat radii of $0.077-0.205 \mu \mathrm{m}$, and air-water capillary entry pressure of $93-599 \mathrm{kPa}$. The porosity of these core samples is similar to shipboard porosity determined from moisture and density (MAD) analyses. Bulk cuttings ( $>4 \mathrm{~mm}$ size fraction) from 928 to 1980 mbsf in the inner wedge of the accretionary prism have porosity of $0.21-0.44$, median pore throat radii of $0.021-0.032 \mu \mathrm{m}$, and air-water capillary entry pressure of $119-982 \mathrm{kPa}$. The porosity of these bulk cuttings is lower than the MAD-determined porosity on bulk cuttings from the same size fraction but is consistent with core-based, MAD-derived porosity from Hole C0002B and with MAD-derived porosity on intact, undisturbed cuttings. Core samples across the lithologic Unit III-IV transition document porosity of $0.34-0.42$, median pore throat radii of $0.041-0.076 \mu \mathrm{m}$, and air-water capillary entry pressure of $121-979 \mathrm{kPa}$. These results suggest that in situ porosity can be estimated from core samples, intact undisturbed cuttings, and/or MICP analyses. Additional postexpedition research will help relate median pore throat radii and capillary entry pressure data to transport properties of these mud(stones).
\end{abstract}

\section{Introduction}

Integrated Ocean Drilling Program (IODP) Expedition 338 was designed to extend and case riser Hole C0002F from 856 to 3600 meters below the seafloor (mbsf). Due to damage to the intermediate flex joint of the riser system, Expedition 338 suspended operations in Hole C0002F at 2005.5 mbsf and continued with riserless operations at Sites C0002, C0012, C0018, C0021, and C0022 (Moore et al., 2014; Strasser et al., 2014a). Expedition 338 was part of the Nankai Trough Seismogenic Zone Experiment (NanTroSEIZE), a multiexpedition scientific project to investigate fault mechanics and seismogenesis along a subduction megathrust, which includes the goals to understand faulting, deformation, and hydrological processes in the vicinity of the plate boundary 
and megasplay faults along the Nankai convergent margin (Tobin and Kinoshita, 2006).

At Site C0002 (Fig. F1), the specific scientific objectives were to sample the Kumano forearc basin sediment and gas hydrate zone, to examine the Kumano forearc basin-accretionary prism unconformity, and to sample the upper portion of the inner wedge of the accretionary prism. Data and samples were collected to characterize the gas hydrate zone; to define the composition, age, and stratigraphy; to investigate the mechanical and hydrologic properties of the system; and to characterize the overall structural evolution of the accretionary prism.

To help define the physical and hydrological properties of sediment of Site C0002, I performed mercury injection capillary pressure (MICP) measurements on bulk cuttings (>4 mm fraction) and core samples. This work complements other geotechnical and sedimentological work within the NanTroSEIZE project to help understand fluid flow, solute/heat transport, and overpressure in the Nankai convergent margin system (e.g., Guo et al., 2013; Ikari et al., 2009; Kitajima et al., 2012; Rowe et al., 2012; Schumann et al., 2014; Tobin and Saffer, 2009).

\section{Methods and materials}

A total of 19 bulk cuttings and core samples (Table T1) were collected shipboard, sealed in storage bags, and stored at $4^{\circ} \mathrm{C}$ until they were prepared for MICP measurements at Core Laboratories (Houston, Texas). Bulk cuttings samples were selected from the $>4 \mathrm{~mm}$ cuttings fraction, and each bulk cuttings sample contained at least $12 \mathrm{~cm}^{3}$ of material. Core samples were core pieces with a total volume exceeding $12 \mathrm{~cm}^{3}$. All samples were selected because they were mud or mudstone. No sand-bearing samples were collected or analyzed.

\section{Mercury injection capillary pressure measurements}

MICP measurements were performed at room temperature $\left(20^{\circ} \mathrm{C}\right)$ using a Micromeritics AutoPore device. Before the measurements, samples were ovendried at $115^{\circ} \mathrm{C}$ for at least $24 \mathrm{~h}$ to allow weight equilibrium $( \pm 0.001 \mathrm{~g})$; this is the standard approach at Core Laboratories and is similar to the moisture and density drying technique of $100^{\circ} \mathrm{C}$ for $24 \mathrm{~h}$ (Blum, 1997). For the MICP measurements, each sample was immersed in mercury in a pressure-sealed chamber attached to a capillary stem with a cylindrical coaxial capacitor. The mercury pressure was increased incrementally from 0 to $380,000 \mathrm{kPa}$. Each pressure step forced mercury intrusion into sample pore spaces, and each pressure step was maintained until volume equilibrium was reached. Volume equilibrium was determined by the capacitance of the system. The volume of mercury injected at each pressure increment was determined by capacitance measurements. Pore volume was computed from the bulk sample volume determined by immersion in mercury, and porosity was determined following the method of Blum (1997). Details about MICP experimental setup, experimental procedure, and interpretation of MICP results can be found in Amyx et al. (1960), Bear (1972), Peters (2012), and Purcell (1949).

The volume of mercury injected and the pore volume at each pressure were used to construct a pore size distribution for each sample. Mercury injection pressure $\left(P_{\mathrm{Hg}}\right)$ was converted to pore throat radius $\left(r_{\mathrm{p}}\right)$ using the Young-Laplace equation:

$$
r_{\mathrm{p}}=\frac{2 \sigma_{\mathrm{Hg}} \cos \theta_{\mathrm{Hg}}}{P_{\mathrm{Hg}}},
$$

where $\sigma_{\mathrm{Hg}}$ is air-mercury interfacial tension $(0.485 \mathrm{~N} / \mathrm{m})$ and $\theta_{\mathrm{Hg}}$ is the mercury-sediment contact angle $\left(140^{\circ}\right)$ (Table T2). The median pore throat radius $\left(r_{50}\right)$ was defined from the pore throat size distribution as the pore throat size at a mercury saturation equal to 0.5 .

Mercury injection pressure $\left(P_{\mathrm{Hg}}\right)$ was converted to air-water capillary pressure $\left(P_{\mathrm{c}}\right)$ by:

$$
P_{\mathrm{c}}=\frac{\sigma_{\mathrm{aw}} \cos \theta_{\mathrm{aw}}}{\sigma_{\mathrm{Hg}} \cos \theta_{\mathrm{Hg}}} P_{\mathrm{Hg}},
$$

where $\sigma_{\mathrm{aw}}$ is air-water interfacial tension $(0.072 \mathrm{~N} / \mathrm{m})$ and $\theta_{\mathrm{aw}}$ is the air-water contact angle $\left(180^{\circ}\right)$ (Table T2). Air-water capillary entry pressure $\left(P_{\text {centry }}\right)$ was determined from the minimum mercury injection pressure at which the volume of injected mercury was nonzero. This corresponds to the mercury percolation threshold (Bear, 1972).

\section{Results}

Porosity data of MICP samples range from 0.21 to 0.56 and show a general decrease with increasing depth (Fig. F2; Table T1). Lithologic Unit II has the highest porosity (0.41-0.56) and Unit V has the lowest porosity (0.21-0.24). All MICP experimental data and injection pressure curves are provided in MICPDATA in Supplementary material (Tables S1-S19; Figs. S1-S19).

MICP sample porosity is comparable to porosity of core samples and of intact undisturbed (formation) cuttings determined shipboard (Expedition 315 Scientists, 2009; Strasser et al., 2014b) by moisture and density measurements (Blum, 1997) but is consistently lower than porosity of bulk cuttings samples 
(Fig. F3). MICP sample porosity and shipboard porosity in lithologic Unit II are high and cover the same range. Near the Unit III/IV boundary, MICP sample porosity and shipboard porosity cover the same range and are generally lower than porosity of bulk cuttings. In Units IV and V, porosity of MICP samples and intact undisturbed cuttings are similar and lower than MAD-derived porosity on bulk cuttings. Shipboard comparison of (1) bulk cuttings, (2) intact undisturbed cuttings, and (3) core samples are used to interpret that elevated porosity in bulk cuttings is due to drilling disturbance (Strasser et al., $2014 \mathrm{~b}$ ). Further research is required to understand the amount of disturbance and the appropriate techniques for estimating in situ porosity where samples may be disturbed (i.e., bulk cuttings).

Median pore throat radius $\left(r_{50}\right)$ determined from MICP measurements ranges from 0.0208 to 0.205 $\mu \mathrm{m}$ (Fig. F2; Table T1). Median pore throat radius in lithologic Unit II increases from 0.133 to $0.205 \mu \mathrm{m}$ at $221-280 \mathrm{mbsf}$ and then decreases to $0.0771 \mu \mathrm{m}$ by 464 mbsf. In Units III-V (904-1980 mbsf), $r_{50}$ decreases from 0.0764 to $0.0208 \mu \mathrm{m}$.

Air-water capillary entry pressure $\left(P_{\text {centry }}\right)$ determined from MICP measurements ranges from 93 to $982 \mathrm{kPa}$ (Fig. F2; Table T1). $P_{\text {centry }}$ data in lithologic Unit II may indicate an increase with increasing depth but are highly variable $(93-599 \mathrm{kPa}) . P_{\text {centry }}$ data in Units III-V are highly variable (119-982 kPa), show significant scatter, and do not indicate any trends with depth or with unit.

\section{Summary}

MICP measurements provide detailed porosity, median pore throat radius, and air-water capillary entry pressure characterization of 19 samples from Site C0002. Porosity decreases downhole, with the highest values in lithologic Unit II and the lowest values in Unit V. Median pore throat radius is highest and has the largest range in Unit II then decreases downhole in Units III-V. Air-water capillary entry pressure values have significant scatter and do not show any trend with lithologic unit or depth. Additional research on permeability of mud(stone) from Site C0002 can be used to understand how permeability may relate to porosity (e.g., Gamage et al., 2011; Schneider et al., 2011) or to pore throat radius (e.g., $\mathrm{GaO}$ and $\mathrm{Hu}, 2013)$. The similarity of MICP-based porosity to porosity of intact, undisturbed cuttings and core samples suggests MICP experiments may be an effective technique to evaluate in situ porosity.

\section{Acknowledgments}

Samples and data were provided by the Integrated Ocean Drilling Program (IODP). Funding was provided by a postexpedition award from the Consortium for Ocean Leadership.

\section{References}

Amyx, J.W., Bass, D.M., and Whiting, R.L., 1960. Petroleum Reservoir Engineering: New York (McGraw-Hill).

Bear, J., 1972. Dynamics of Fluids in Porous Media: New York (Elsevier).

Blum, P., 1997. Physical properties handbook: a guide to the shipboard measurement of physical properties of deep-sea cores. Ocean Drilling Program Technical Note, 26. doi:10.2973/odp.tn.26.1997

Expedition 314 Scientists, 2009. Expedition 314 Site C0002. In Kinoshita, M., Tobin, H., Ashi, J., Kimura, G., Lallemant, S., Screaton, E.J., Curewitz, D., Masago, H., Moe, K.T., and the Expedition 314/315/316 Scientists, Proceedings of the Integrated Ocean Drilling Program, 314/ 315/316: Washington, DC (Integrated Ocean Drilling Program Management International, Inc.). doi:10.2204/iodp.proc.314315316.114.2009

Expedition 315 Scientists, 2009. Expedition 315 Site C0002. In Kinoshita, M., Tobin, H., Ashi, J., Kimura, G., Lallemant, S., Screaton, E.J., Curewitz, D., Masago, H., Moe, K.T., and the Expedition 314/315/316 Scientists, Proceedings of the Integrated Ocean Drilling Program, 314/ 315/316: Washington, DC (Integrated Ocean Drilling Program Management International, Inc.). doi:10.2204/iodp.proc.314315316.124.2009

Gamage, K., Screaton, E., Bekins, B., and Aiello, I., 2011. Permeability-porosity relationships of subduction zone sediments. Marine Geology, 279(1-4):19-36. doi:10.1016/j.margeo.2010.10.010

Gao, Z., and $\mathrm{Hu}$, Q., 2013. Estimating permeability using median pore-throat radius obtained from mercury intrusion porosimetry. Journal of Geophysics and Engineering, 10(2):025014. doi:10.1088/1742-2132/10/2/ 025014

Guo, J., Underwood, M.B., Likos, W.J., and Saffer, D.M., 2013. Apparent overconsolidation of mudstones in the Kumano Basin of southwest Japan: implications for fluid pressure and fluid flow within a forearc setting. Geochemistry, Geophysics, Geosystems, 14(4):1023-1038. doi:10.1029/2012GC004204

Heki, K., 2007. Secular, transient, and seasonal crustal movements in Japan from a dense GPS array: implication for plate dynamics in convergent boundaries. In Dixon, T.H., and Moore, J.C. (Eds.), The Seismogenic Zone of Subduction Thrust Faults: New York (Columbia Univ. Press), 512-539.

Ikari, M.J., Saffer, D.M., and Marone, C., 2009. Frictional and hydrologic properties of a major splay fault system, 
Nankai subduction zone. Geophysical Research Letters, 36(20):L20313. doi:10.1029/2009GL040009

Kitajima, H., Chester, F.M., and Biscontin, G., 2012. Mechanical and hydraulic properties of Nankai accretionary prism sediments: effect of stress path. Geochemistry, Geophysics, Geosystems, 13(10):Q0AD27. doi:10.1029/2012GC004124

Moore, G., Kanagawa, K., Strasser, M., Dugan, B., Maeda, L., and Toczko, S., 2014. IODP Expedition 338: NanTroSEIZE Stage 3: NanTroSEIZE plate boundary deep riser 2. Scientific Drilling, 17:1-12. doi:10.5194/sd-17-1-2014

Peters, E.J., 2012. Advanced Petrophysics: Volume 2: Dispersion, Interfacial Phenomena/Wettability, Capillarity/Capillary Pressure, Relative Permeability: Austin, TX (Live Oak Book Company).

Purcell, W.R., 1949. Capillary pressures-their measurement using mercury and the calculation of permeability therefrom. Journal of Petroleum Technology,1(2):39-48. doi:10.2118/949039-G

Rowe, K.T., Screaton, E.J., and Ge, S., 2012. Coupled fluid flow and deformation modeling of the frontal thrust region of the Kumano Basin transect, Japan: implications for fluid pressures and décollement downstepping. Geochemistry, Geophysics, Geosystems, 13:Q0AD23. doi:10.1029/2011GC003861

Schumann, K., Behrmann, J.H., Stipp, M., Yamamoto, Y., Kitamura, Y., and Lempp, C., 2014. Geotechnical behavior of mudstones from the Shimanto and Boso accretionary complexes, and implications for the Nankai accretionary prism. Earth, Planets and Space, 66:129. doi:10.1186/1880-5981-66-129

Seno, T., Stein, S., and Gripp, A.E., 1993. A model for the motion of the Philippine Sea plate consistent with NUVEL-1 and geological data. Journal of Geophysical Research: Solid Earth, 98(B10):17941-17948. doi:10.1029/93JB00782

Schneider, J., Flemings, P.B., Day-Stirrat, R.J., and Germaine, J.T., 2011. Insights into pore-scale controls on mudstone permeability through resedimentation experiments. Geology, 39(11):1011-1014. doi:10.1130/ G32475.1

Strasser, M., Dugan, B., Kanagawa, K., Moore, G.F., Toczko, S., Maeda, L., Kido, Y., Moe, K.T., Sanada, Y., Esteban, L.,
Fabbri, O., Geersen, J., Hammerschmidt, S., Hayashi, H., Heirman, K., Hüpers, A., Jurado Rodriguez, M.J., Kameo, K., Kanamatsu, T., Kitajima, H., Masuda, H., Milliken, K., Mishra, R., Motoyama, I., Olcott, K., Oohashi, K., Pickering, K.T., Ramirez, S.G., Rashid, H., Sawyer, D., Schleicher, A., Shan, Y., Skarbek, R., Song, I., Takeshita, T., Toki, T., Tudge, J., Webb, S., Wilson, D.J., Wu, H.-Y., and Yamaguchi, A., 2014a. Expedition 338 summary. In Strasser, M., Dugan, B., Kanagawa, K., Moore, G.F., Toczko, S., Maeda, L., and the Expedition 338 Scientists, Proceedings of the Integrated Ocean Drilling Program, 338: Yokohama (Integrated Ocean Drilling Program). doi:10.2204/iodp.proc.338.101.2014

Strasser, M., Dugan, B., Kanagawa, K., Moore, G.F., Toczko, S., Maeda, L., Kido, Y., Moe, K.T., Sanada, Y., Esteban, L., Fabbri, O., Geersen, J., Hammerschmidt, S., Hayashi, H., Heirman, K., Hüpers, A., Jurado Rodriguez, M.J., Kameo, K., Kanamatsu, T., Kitajima, H., Masuda, H., Milliken, K., Mishra, R., Motoyama, I., Olcott, K., Oohashi, K., Pickering, K.T., Ramirez, S.G., Rashid, H., Sawyer, D., Schleicher, A., Shan, Y., Skarbek, R., Song, I., Takeshita, T., Toki, T., Tudge, J., Webb, S., Wilson, D.J., Wu, H.-Y., and Yamaguchi, A., 2014b. Site C0002. In Strasser, M., Dugan, B., Kanagawa, K., Moore, G.F., Toczko, S., Maeda, L., and the Expedition 338 Scientists, Proceedings of the Integrated Ocean Drilling Program, 338: Yokohama (Integrated Ocean Drilling Program). doi:10.2204/ iodp.proc.338.103.2014

Tobin, H.J., and Kinoshita, M., 2006. NanTroSEIZE: the IODP Nankai Trough Seismogenic Zone Experiment. Scientific Drilling, 2:23-27. doi:10.2204/ iodp.sd.2.06.2006

Tobin, H.J., and Saffer, D.M., 2009. Elevated fluid pressure and extreme mechanical weakness of a plate boundary thrust, Nankai Trough subduction zone. Geology, 37(8):679-682. doi:10.1130/G25752A.1

Initial receipt: 11 August 2014

Acceptance: 7 May 2015

Publication: 19 August 2015

MS 338-202 
Figure F1. Location map showing Site C0002 and other IODP sites in the NanTroSEIZE study region. Black outline is the 3-D seismic data region. Yellow arrows are estimated far-field vectors between the Philippine Sea plate and Japan (Seno et al., 1993; Heki, 2007). Stars are the locations of the 1944 and 1946 tsunamigenic earthquakes.

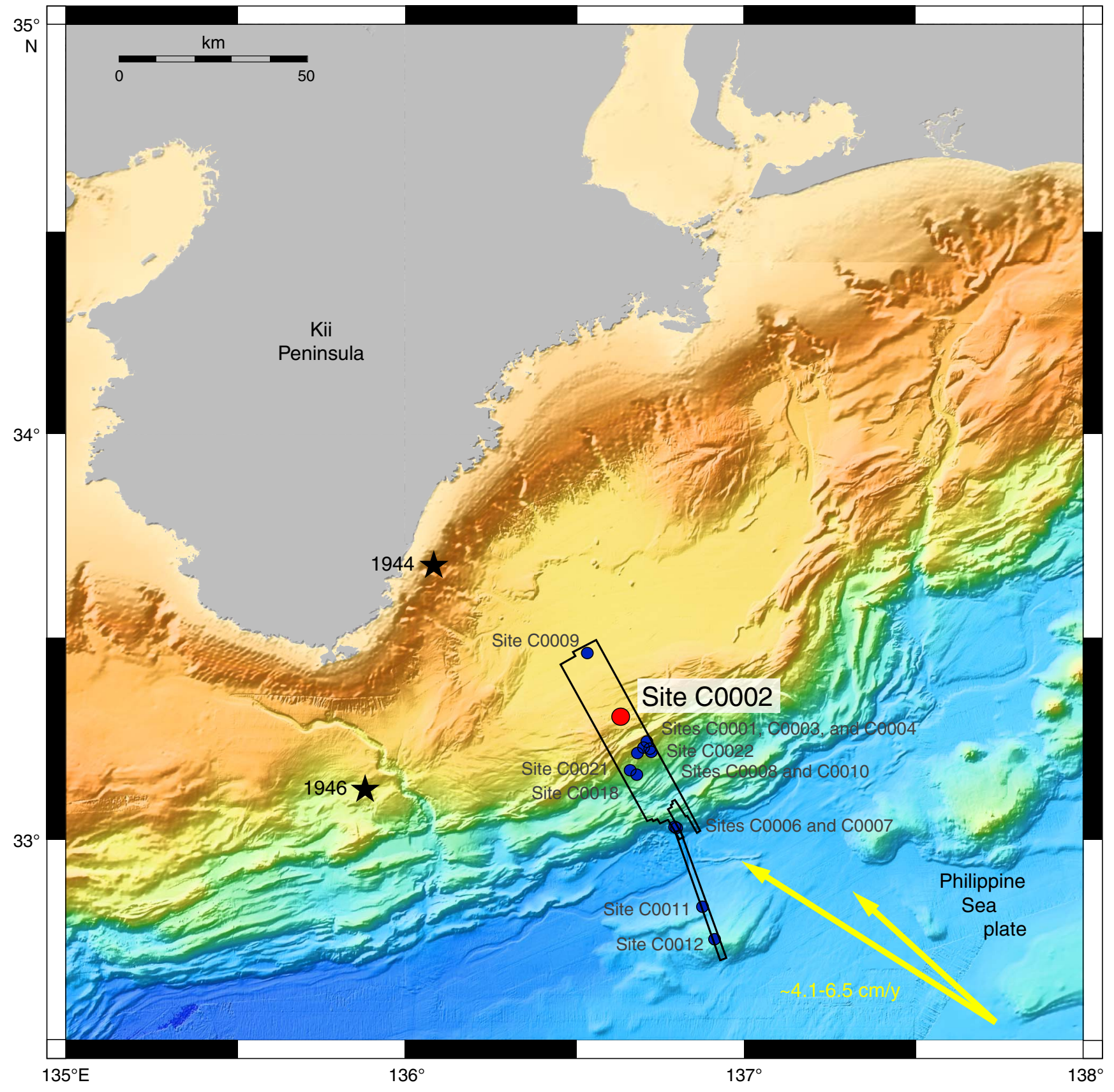


Figure F2. Results of mercury injection capillary pressure (MICP) measurements, Site C0002. A. Porosity. B. Median pore throat radius $\left(r_{50}\right)$. C. Air-water capillary entry pressure $\left(P_{\text {centry }}\right)$. Gray-shaded boundary between Units III and IV shows the variability in the depth of the boundary based on sampling during IODP Expeditions 314, 315, and 338 (Expedition 314 Scientists, 2009; Expedition 315 Scientists, 2009; Strasser et al., 2014b).

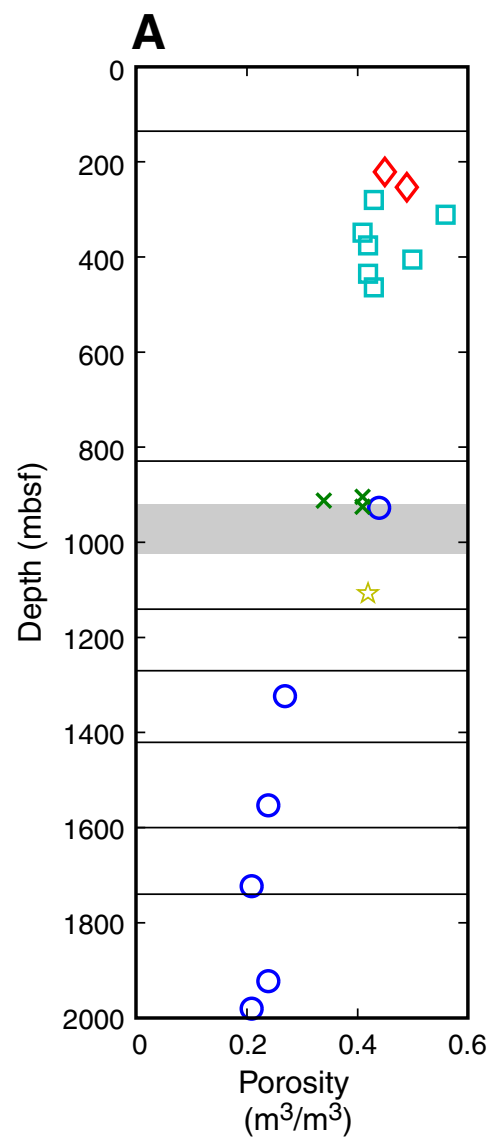

B

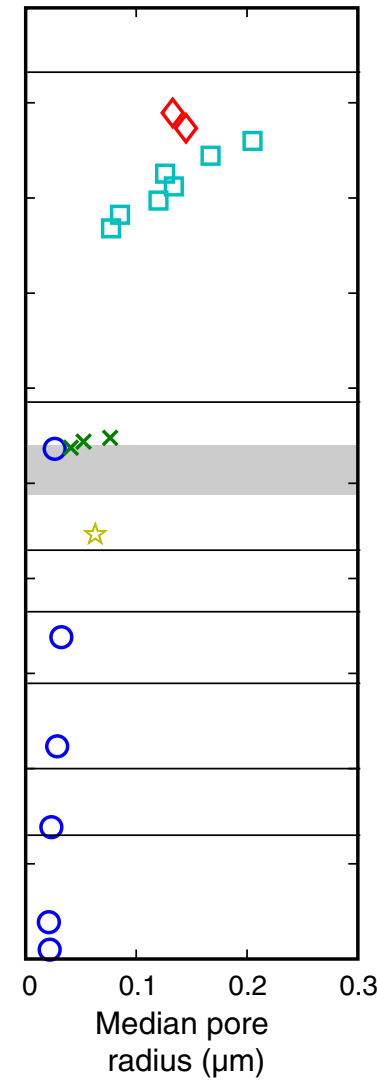

O Hole C0002F cuttings (MICP)

is Hole $\mathrm{C0002 \textrm {H }}$ core sample (MICP)

$\times$ Hole C0002J core sample (MICP)

$\diamond$ Hole C0002K core sample (MICP)

$\square$ Hole C0002L core sample (MICP)
C

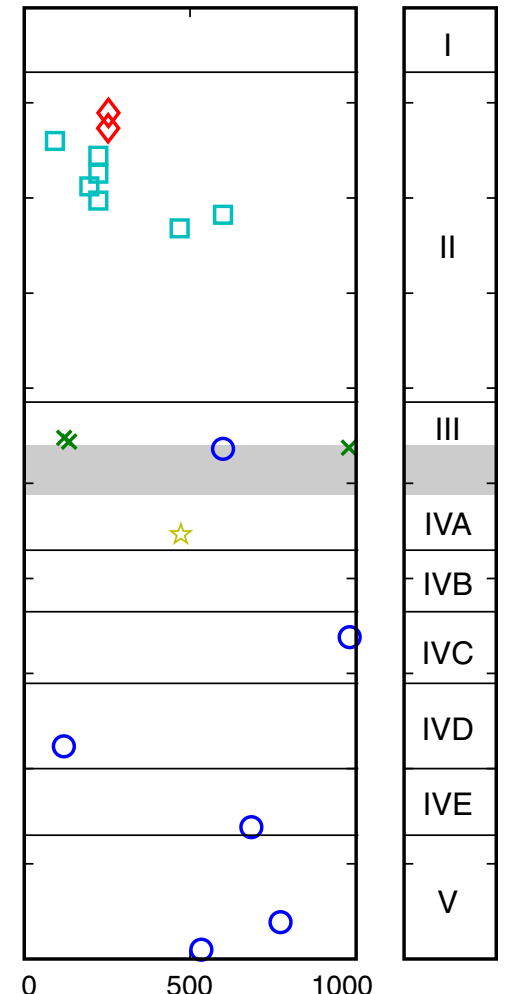

Capillary entry Lith. pressure $(\mathrm{kPa})$

unit 
Figure F3. Comparison of porosity from mercury injection capillary pressure (MCIP) measurement samples and porosity of shipboard samples determined by moisture and density (MAD) (Blum, 1997), Site C0002. Grayshaded boundary between Units III and IV shows the variability in the depth of the boundary based on sampling during IODP Expeditions 314, 315, and 338 (Expedition 314 Scientists, 2009; Expedition 315 Scientists, 2009; Strasser et al., 2014b).

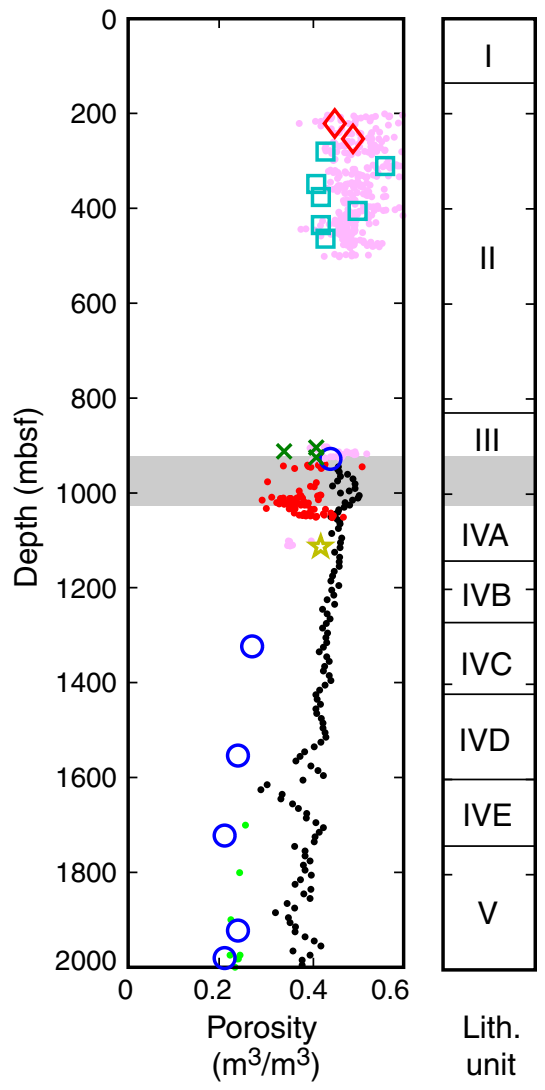

\footnotetext{
Hole C0002F cuttings (MICP)

- Hole C0002F bulk cuttings (MAD)

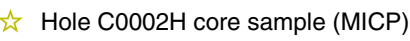

- Hole C0002F intact, undisturbed cuttings (MAD)

$\times$ Hole C0002J core sample (MICP)

Hole $\mathrm{C0002H} / \mathrm{J} / \mathrm{K}$ core sample (MAD)

$\diamond$ Hole C0002K core sample (MICP)

- Hole C0002B core sample (MAD)
} 
Table T1. Sample summary and data from mercury injection capillary pressure measurements, Site C0002.

\begin{tabular}{lrlllrrr}
\hline Hole, core, section & $\begin{array}{r}\text { Depth } \\
(\mathrm{mbsf})\end{array}$ & Sample type & Lithologic unit & $\begin{array}{c}\phi \\
\left(\mathrm{m}^{3} / \mathrm{m}^{3}\right)\end{array}$ & $\begin{array}{c}r_{50} \\
(\mu \mathrm{m})\end{array}$ & $\begin{array}{r}P_{\text {Hgentry }} \\
(\mathrm{kPa})\end{array}$ & \multicolumn{1}{c}{$\begin{array}{c}P_{\text {centry }} \\
(\mathrm{kPa})\end{array}$} \\
\hline 338- & & & & & & & \\
C0002F-21, SMW & 928.00 & Bulk cuttings & III & 0.44 & 0.0265 & 3089 & 599 \\
C0002F-110SMW & 1323.00 & Bulk cuttings & IVA & 0.27 & 0.0325 & 5068 & 982 \\
C0002F-167SMW & 1553.00 & Bulk cuttings & IVD & 0.24 & 0.0289 & 615 & 119 \\
C0002F-211SMW & 1723.00 & Bulk cuttings & IVE & 0.21 & 0.0236 & 3530 & 684 \\
C0002F-267SMW & 1923.00 & Bulk cuttings & V & 0.24 & 0.0208 & 3985 & 772 \\
C0002F-312SMW & 1980.00 & Bulk cuttings & V & 0.21 & 0.0222 & 2758 & 534 \\
C0002H-2R-1 & 1110.58 & Core specimen & IV & 0.42 & 0.0604 & 2434 & 472 \\
C00022-1R-7 & 904.31 & Core specimen & III & 0.41 & 0.0764 & 622 & 121 \\
C0002)-3R-1 & 912.29 & Core specimen & III & 0.34 & 0.0523 & 703 & 136 \\
C0002)-5R-7 & 925.23 & Core specimen & III & 0.41 & 0.0409 & 5054 & 979 \\
C0002K-5T-2 & 221.23 & Core specimen & II & 0.45 & 0.1330 & 1310 & 254 \\
C0002K-8X-5 & 253.50 & Core specimen & II & 0.49 & 0.1450 & 1303 & 253 \\
C0002L-1X-3 & 280.11 & Core specimen & II & 0.43 & 0.2050 & 479 & 93 \\
C0002L-4X-6 & 311.08 & Core specimen & II & 0.56 & 0.1670 & 1158 & 224 \\
C0002L-8X-6 & 348.87 & Core specimen & II & 0.41 & 0.1260 & 1158 & 224 \\
C0002L-11X-5 & 375.88 & Core specimen & II & 0.42 & 0.1340 & 1014 & 197 \\
C0002L-14X-5 & 405.59 & Core specimen & II & 0.50 & 0.1200 & 1158 & 224 \\
C0002L-17X-7 & 435.42 & Core specimen & II & 0.42 & 0.0854 & 3089 & 599 \\
C0002L-20X-6 & 464.00 & Core specimen & II & 0.43 & 0.0771 & 2420 & 469 \\
\hline
\end{tabular}

See Strasser et al. (2014b) for description of depth determination of cuttings. $\phi=$ porosity, $r_{50}=$ median pore throat radius, $P_{\text {Hgentry }}=$ mercury injection pressure at mercury percolation threshold, $P_{\text {centry }}=$ air-water capillary entry pressure.

Table T2. Nomenclature.

\begin{tabular}{llcc}
\hline Variable & \multicolumn{1}{c}{ Definition } & Dimension & Unit \\
\hline$P_{\mathrm{c}}$ & Air-water capillary pressure & $\mathrm{M} / \mathrm{LT}^{2}$ & $\mathrm{kPa}$ \\
$P_{\text {centry }}$ & Air-water capillary entry pressure & $\mathrm{M} / \mathrm{LT}^{2}$ & $\mathrm{kPa}$ \\
$P_{\mathrm{Hg}}$ & Mercury injection pressure & $\mathrm{M} / \mathrm{LT}^{2}$ & $\mathrm{kPa}$ \\
$P_{\mathrm{Hgentry}}$ & Mercury injection pressure at mercury percolation threshold & $\mathrm{M} / \mathrm{LT}^{2}$ & $\mathrm{kPa}$ \\
$r_{50}$ & Median pore throat radius & $\mathrm{L}$ & $\mu \mathrm{m}$ \\
$r_{\mathrm{p}}$ & Pore throat radius & $\mathrm{L}$ & $\mathrm{m}$ \\
$\theta_{\mathrm{aw}}$ & Air-water contact angle & Dimensionless & - \\
$\theta_{\mathrm{Hg}}$ & Mercury-sediment contact angle & Dimensionless & - \\
$\sigma_{\mathrm{aw}}$ & Air-water interfacial tension & $\mathrm{M} / \mathrm{T}^{2}$ & $\mathrm{~N} / \mathrm{m}$ \\
$\sigma_{\mathrm{Hg}}$ & Air-mercury interfacial tension & $\mathrm{M} / \mathrm{T}^{2}$ & $\mathrm{~N} / \mathrm{m}$ \\
$\phi$ & Porosity & & $\mathrm{m} / \mathrm{m}^{3}$ \\
\hline
\end{tabular}

